\title{
PHYTOMASS MAPPING OF THE "SERIDÓ CAATINGA" VEGETATION BY THE PLANT AREA AND THE NORMALIZED DIFFERENCE VEGETATION INDECES
}

\author{
Thomaz Corrêa e Castro da Costa ${ }^{1 *}$; Luciano José de Oliveira Accioly²; Maria Ap. José de \\ Oliveira3; Nivaldo Burgos²; Flávio Hugo Barreto Batista da Silva² \\ ${ }^{1}$ Embrapa Solos, R. Jardim Botânico, 1024 - CEP: 22460-001 - Rio de Janeiro, RJ. \\ ${ }^{2}$ Embrapa Solos Nordeste, R. Antônio Falcão, 402 - CEP: 51020-240 - Recife, PE. \\ ${ }^{3} \mathrm{CNPq}$ Fellow. \\ *Corresponding author <thomaz@cnps.embrapa.br>
}

\begin{abstract}
Phytomass is a critical information for economic and environmental activities like the establishment of policies for timber resources, forest management, studies of plant nutrient cycling, $\mathrm{CO}_{2}$ sink, among other. The phytomass of a Caatinga area was obtained by an empirical method using normalized difference vegetation index (NDVI) of Landsat images, the plant area index (PAI) and the phytomass inventory. At a first stage, linear, logarithmic and non-linear models were developed and tested. Bush and tree specimens were considered in the study, so that most of the individuals that contribute to the spectral answer detected by satellite images were included. At a second stage, the orbital parameter NDVI was used to map the PAI, which was used to map the phytomass, based on the relationship of this phytomass as a function of PAI. The residues between measurements and estimates based on NDVI varied from 0 to $84 \%$, while the residues of total dry weight of phytomass per ha obtained by mapping and by dendrometrical equations varied from 5 to $104 \%$, with a large trend of 166 and $448 \%$ in open Caatinga areas, due to the contribution of the herbaceous stratum to NDVI.

Key words: $\mathrm{CO}_{2}$, LAI, aboveground biomass, desertification
\end{abstract}

\section{MAPEAMENTO DA FITOMASSA DA CAATINGA DO SERIDÓ PELOS ÍNDICES DE ÁREA DE PLANTA E DE VEGETAÇÃO DA DIFERENÇA NORMALIZADA}

\begin{abstract}
RESUMO: A fitomassa, principalmente arbórea, é informação necessária em atividades econômicas e ambientais, como políticas de uso do recurso madeireiro, manejo florestal, estudos de ciclagem de nutrientes, absorção de $\mathrm{CO}_{2}$, entre outros. A finalidade deste estudo foi a verificação de um método empírico para 0 mapeamento da fitomassa da Caatinga do Seridó, integrando-se um inventário de fitomassa, o índice de área de planta (IAP) e o índice de vegetação da diferença normalizada (NDVI), por meio de imagens Landsat TM. Na primeira etapa foram desenvolvidos e testados modelos lineares, logarítmicos e não lineares. A abordagem de tamanho foi arbustiva e arbórea, incluindo-se a maior parte dos indivíduos que contribuem na resposta espectral mensurada por imagens de satélite. Em uma segunda etapa utilizamos o parâmetro orbital, NDVI, para o mapeamento do IAP, que por sua vez, foi utilizado para mapear a fitomassa. Os desvios entre mensurações de IAP e estimativas a partir do NDVI, variaram de 0 a $84 \%$, enquanto que os desvios entre Peso Seco Total de Fitomassa por ha obtidos pelo mapeamento e por equações dendrométricas, variaram de 5 a 104\%, com grandes tendências de 166 e 448\% para áreas de caatinga aberta, provocada pela contribuição do estrato herbáceo no NDVI.

Palavras-chave: $\mathrm{CO}_{2}$, LAI, biomassa aérea, desertificação
\end{abstract}

\section{INTRODUCTION}

Phytomass, mainly tree phytomass, is an information required for economic and environmental activities such as the development of policies for the use of timber resources, forest management, nutrient cycling, and $\mathrm{CO}_{2}$ sink, among other (Brown et al., 1989; Souza \& Jesus, 1991; Bohrer \& Campos, 1993; Silva et al., 1993a; Scolforo et al., 1993; Foody et al., 1996). Since the destructure assessment of phytomass is the most laborintensive stage of a forest inventory, and considering also the environmental damages, non-destructive measurement methods are required in this type of study.
One of the methods under study (Pereira, 1985; Santos, 1988; Kazmierczak, 1992; Amaral et al., 1996; Jakubauskas \& Price, 1997; Santos et al., 1998; Xavier et al., 1998; Linhares et al., 2000; Qi et al., 2000), is based on empirical relationships between phytomass and radiation measured by orbital sensors, allowing for the use of the plant area index (PAI) as an intermediate variable.

PAI is a better term for the commonly used concept of leaf area index (LAI) measured in the field. This new concept was defined by White et al. (2000) and it includes trunks and branches, which in semi-arid regions will probably represent a more significant contribution to PAI, when compared to other biomes. 
Thus, LAI can be calculated by subtracting the trunk and branch index (IAG) from PAI, measured in the dry season, when all leaves fall.

Santos et al. (1998) established a relationship between backscattering coeficient $(\mathrm{dB})$ of a JERS-1 image and phytomass values for areas of primary forest and Amazon secondary succession forest, with $R^{2}=0.429$. This was improved by combining bands 3 and 5 of the Landsat TM sensor, to $R^{2}=0.77$. Using only Landsat TM images, Amaral et al. (1996), for the secondary succession of abandoned areas of the Amazon forest, established linear relationships between the normalized difference vegetation index (NDVI) and LAI, and NDVI and the basal area $\left(\mathrm{cm}^{2} \mathrm{ha}^{-1}\right)$, with $\mathrm{R}^{2}=0.77$. These results were thought to exceed expectations when compared to those of Box et al. (1989), referred by Amaral et al. (1996), with $r=0.234$ between LAl and $\mathrm{NDVI}$, and $\mathrm{r}=0.344$ between NDVI and phytomass. For Pinus, Jakubauskas \& Price (1997) obtained $R^{2}=0.62$ for LAI as a function of NDVI, and the greenness component of the transformation Tasseled Cap, and $\mathrm{R}^{2}=$ 0.59 for the phytomass as a function of NDVI. Kazmierckak (1992) found for Pinus and Araucaria angustifolia that the best variable for the relationship with orbital parameters was the basal area, with Landsat TM band 5 for both populations, however with a poor adjustment $\left(R^{2}=0.3594\right.$ for Araucaria angustifolia, and $R^{2}=0.6593$ for Pinus).

In semi-arid regions, there are fewer possibility of NVDI saturation, because of the low phytomass density, mainly leaf density, a condition that was not found in more advanced stages of the Amazon forest, in which, its correlation with the LAl is limited in more advanced stages of vegetation succession. Sader et al. (1990) and Honzak et al. (1995) cited by Amaral et al. (1996), showed that the NDVI and the LAl are better correlated when they are obtained in areas in initial succession stages or up to 30 years of age, where lower phytomass values occur. The best NDVI-LAI relationships were obtained by Qi et al. (2000), who adjusted a polynomial model to LAI data collected in a semi-arid region of the State of Arizona, obtaining inflexion for $L A I>1.2$, when the model takes the exponential form, with constant NDVI results $\cong 0.6$ for $\mathrm{LAI}>2.0$. The assessed coefficient of determination was 0.94 .

To achieve a good correlation of field measured phytomass with PAI and NDVI, in semi-arid regions, it is necessary to adapt the methodology for tree modeling, with the main purpose of estimating the economic portion of the forest resource for energy, timber or pulp uses of planted forests (Paula Neto et al., 1992; Guimarães \& Leite, 1992; Leite and Regazzi 1992; Paula Neto \& Rezende, 1992; Silva et al., 1993b) and native forests (Scolforo et al., 1993; Silva et al., 1993a; Souza \& Jesus, 1991; Brown et al., 1989). This is due to the fact that the radiation reflected to the sensor is related to the whole canopy (tree, shrub and herbaceous strata) and in the
Caatinga there is an increased participation of individuals in the lower stratum because of the low leaf density. Thus, size standards and dendrometrical variables were changed, taking into account shrub and tree sizes, and vegetation complexity ( twisting, forking, and deciduous leaves), and this methodology was compared to the method used by Silva (1998) and Ibama (1992a), in phytomass inventories of caatinga biomass.

The objective of this work was to develop a method to map the shrub-tree phytomass at the Seridó caatinga, targeting at the diagnosis of the distribution of phytomass stock as input for desertification zoning, forest management programs and carbon cycling studies.

This study comprises a stage of various investigations related to land use in the caatinga biome, such as desertification, climate change, and nonsustainable use of timber resources, which have been causing losses of the floristic diversity and soil degradation of the Seridó caatinga ecosystem.

\section{MATERIAL AND METHODS}

\section{Study Area}

The pilot area for data collection covers a $30 \mathrm{x}$ $25 \mathrm{~km}$ (75000 ha) rectangle, with an average altitude of $270 \mathrm{~m}$ ranging from 200 to $700 \mathrm{~m}$, inside the Seridó Desertification Nucleus (Rio Grande do Norte/Paraíba, Brazil), (Figure 1).

\section{Phytomass Modeling}

Phytomass modeling was broken down into three stages (Figure 2). The final result was phytomass mapping assisted by a geographic information system.

\section{Stage 1}

To carry out Phytomass Inventories, the selection of areas for data collection was defined in three levels of densities of the Seridó vegetation (Ibama, 1992a). These levels were selected in the field, to mark transects, phyto-sociological inventory and phytomass collection, also using a spectral similarity criterion (SPRING/INPE segmentation module), of Landsat TM bands 3,4 and 5, totaling a 16 area sample (Table 1).

Quadrant point (Brower et. al, 1998) was the chosen sampling method, using georeferenced $500 \mathrm{~m}$ transects (Table 1), with accuracy estimated (EPE) between 3 and $5 \mathrm{~m}$. Distance between points was $10 \mathrm{~m}$ and the distance between transects $20 \mathrm{~m}$, totaling 3,469 trees measured and 246 trees cut, representing the most abundant species of Seridó.

To build Phytomass Models by Tree, by Species, we chose to model trees considering forking, resulting in the variable "sum of base circumference" (SCBA), which has a better correlation with phytomass than $\mathrm{SCBA}^{2}$ (sum of $\mathrm{CBA}^{2}$ ), analytically exact, using as tree inclusion the criterion of base diameter (DBA) larger than or equal to $1 \mathrm{~cm}$. Because of the intermediate standards found in the field, we also chose to use models that are not stratified by area. 


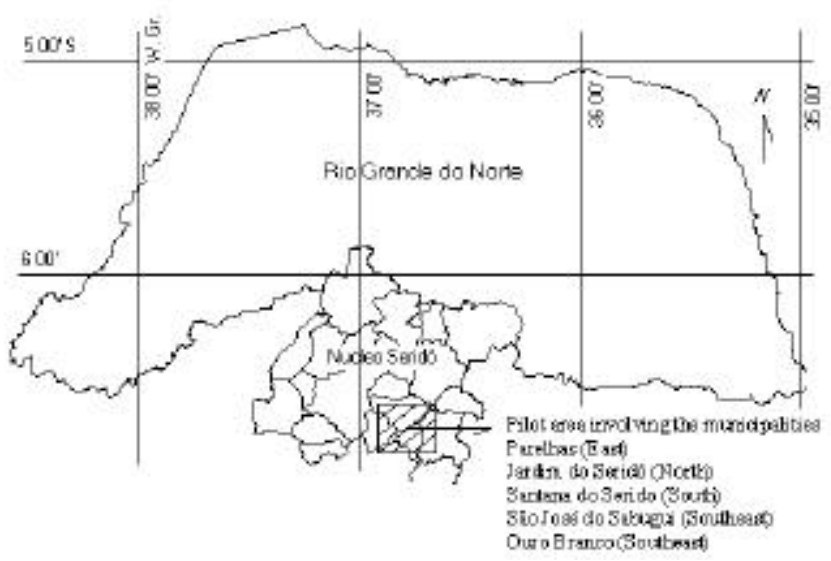

Figure 1- Study Area in the Seridó Desertification Unit (Adapted from CD-ROM-IBGE, 1996).

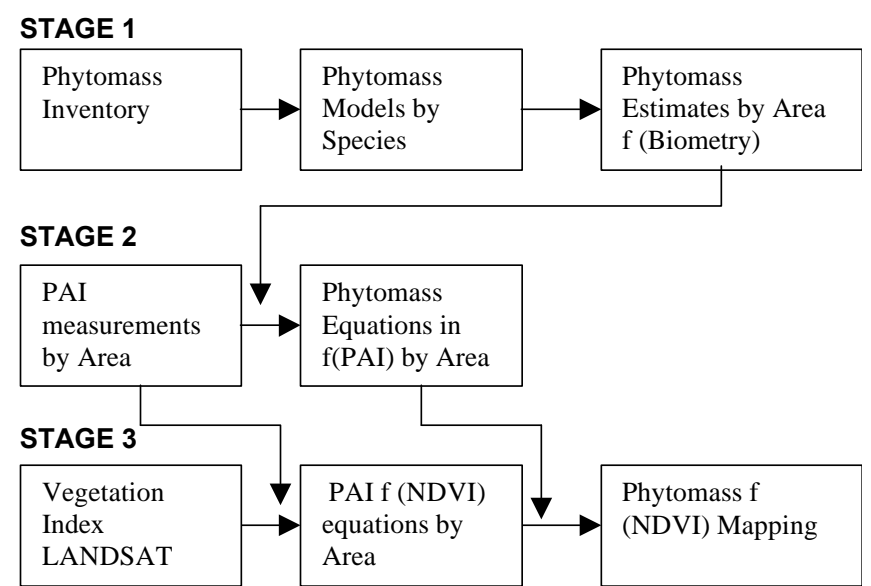

Figure 2 - Flowchart of phytomass mapping operations.

Table 1 - Sampled areas for data collection (Di, CBA, HT, DC2, Vol, PUF, PUG) and plant area index (PAI), with the respective geographic location (X, Y) (UTM Zone 24/SAD69).

\begin{tabular}{|c|c|c|c|c|c|c|}
\hline Farm & ${ }^{1 /} \mathrm{H}^{\prime *}$ & ${ }^{2 / D T} \mathrm{~m}^{-2}$ & $X(m)$ & $\mathrm{Y}(\mathrm{m})$ & ${ }^{3 /}$ Measured Var. & "/ Estimated Var. \\
\hline $\begin{array}{l}\text { Canto Alegre (A1)- Dense Caatinga } \\
\text { (Type 4) }\end{array}$ & 1.324 & 0.171 & 739894 & 9271214 & $\begin{array}{l}\text { Di, CBA, HT, DC2, } \\
\text { PUF,PUG Vol, PAI }\end{array}$ & $\begin{array}{l}\text { DWleaf,DWbranch, } \\
\text { Vol, PAI }\end{array}$ \\
\hline $\begin{array}{l}\text { Humaitá(A2) - SEMI-Dense Caatinga } \\
\text { (Type 3) }\end{array}$ & 1.572 & 0.087 & 741277 & 9262942 & $\begin{array}{l}\text { Di, CBA, HT, DC2, } \\
\text { PUF,PUG, Vol, PAI }\end{array}$ & $\begin{array}{l}\text { DWleaf,DWbranch, } \\
\text { Vol, PAI }\end{array}$ \\
\hline $\begin{array}{l}\text { São Roque(A3)-Open Caatinga with } \\
\text { exposed soil (Typo 2) }\end{array}$ & 1.434 & 0.042 & 735957 & 9262790 & $\begin{array}{l}\text { Di, CBA, HT, DC2, } \\
\text { PUF,PUG, Vol, PAI }\end{array}$ & $\begin{array}{l}\text { DWleaf,DWbranch, } \\
\text { Vol, PAI }\end{array}$ \\
\hline $\begin{array}{l}\text { Curucuru (A4) - Intermediary between } \\
\text { Semi-Dense and Open }\end{array}$ & 1.569 & 0.129 & 740975 & 9273535 & $\begin{array}{l}\text { Di, CBA, HT,DC2, } \\
\text { PAI }\end{array}$ & $\begin{array}{l}\text { DWleaf,DWbranch, } \\
\text { Vol, PAI }\end{array}$ \\
\hline $\begin{array}{l}\text { São Gonçalo (A5)-Intermediary between } \\
\text { Semi- Dense and Open }\end{array}$ & 1.744 & 0.117 & 743366 & 9271099 & $\begin{array}{l}\text { Di, CBA, HT,DC2, } \\
\text { PAI }\end{array}$ & $\begin{array}{l}\text { DWleaf,DWbranch, } \\
\text { Vol, PAI }\end{array}$ \\
\hline $\begin{array}{l}\text { Sussua rana (A6) - Open Caatinga with } \\
\text { mallow (malva) and bent (capim panasco) }\end{array}$ & 2.027 & 0.036 & 754763 & 9263184 & $\begin{array}{l}\text { Di, CBA, HT,DC2, } \\
\text { PAI }\end{array}$ & $\begin{array}{l}\text { DWleaf,DWbranch, } \\
\text { Vol, PAI }\end{array}$ \\
\hline $\begin{array}{l}\text { Quintos de Baixo (A7)-Preserved Dense } \\
\text { Caatinga }\end{array}$ & 2.281 & 0.390 & 756513 & 9253222 & $\begin{array}{l}\text { Di, CBA, HT,DC2, } \\
\text { PAI }\end{array}$ & $\begin{array}{l}\text { DWleaf,DWbranch, } \\
\text { Vol, PAI }\end{array}$ \\
\hline $\begin{array}{l}\text { Varzea Barro de Cima (A8)- Presered } \\
\text { Dense Caatinga }\end{array}$ & 1.835 & 0.422 & 757698 & 9254683 & $\mathrm{Di}, \mathrm{CBA}, \mathrm{HT}, \mathrm{PAI}$ & $\begin{array}{l}\text { DWleaf,DWbranch, } \\
\text { Vol, PAI }\end{array}$ \\
\hline $\begin{array}{l}\text { Sítio Açude Fechado do Raul (A9)-Dense } \\
\text { Caatinga with clearings and few } \\
\text { secondary woods }\end{array}$ & 1.533 & 0.305 & 730615 & 9255374 & Di, CBA, HT, PAI & $\begin{array}{l}\text { DWleaf,DWbranch, } \\
\text { Vol, PAI }\end{array}$ \\
\hline $\begin{array}{l}\text { Sítio Riacho dos Campos (A10)-Semi- } \\
\text { Dense degraded Caatinga with clearings }\end{array}$ & 1.811 & 0.113 & 739525 & 9252493 & $\mathrm{Di}, \mathrm{CBA}, \mathrm{HT}, \mathrm{PAI}$ & $\begin{array}{l}\text { DWleaf,DWbranch, } \\
\text { Vol, PAI }\end{array}$ \\
\hline $\begin{array}{l}\text { Carnaubinha de Cima (A11)-Dense } \\
\text { degraded Caatinga uneven relief }\end{array}$ & 1.210 & 0.360 & 733757 & 9256606 & $\mathrm{Di}, \mathrm{CBA}, \mathrm{HT}, \mathrm{PAI}$ & $\begin{array}{l}\text { DWleaf,DWbranch, } \\
\text { Vol, PAI }\end{array}$ \\
\hline $\begin{array}{l}\text { Umburana (A12)-Open degraded } \\
\text { Caatinga }\end{array}$ & 1.084 & 0.103 & 735745 & 9274085 & $\mathrm{Di}, \mathrm{CBA}, \mathrm{HT}, \mathrm{PAI}$ & $\begin{array}{l}\text { DWleaf,DWbranch, } \\
\text { Vol, PAI }\end{array}$ \\
\hline $\begin{array}{l}\text { Cachoeira (A13)-Dense Caatinga with } \\
\text { secondary woods }\end{array}$ & 1.726 & 0.421 & 752427 & 9271905 & Di, CBA, HT, PAI & $\begin{array}{l}\text { DWleaf,DWbranch, } \\
\text { Vol, PAI }\end{array}$ \\
\hline $\begin{array}{l}\text { Poço Salgado (A14)-Dense Caating a } \\
\text { with clearings and few secondary woods }\end{array}$ & 1.809 & 0.229 & 745868 & 9256987 & Di, CBA, HT, PAI & $\begin{array}{l}\text { DWleaf,DWbranch, } \\
\text { Vol, PAI }\end{array}$ \\
\hline $\begin{array}{l}\text { Quintos de Baixo (A15)-Preserved Dense } \\
\text { Caatinga; dense secondary woods; } \\
\text { typical hill vegetation }\end{array}$ & 2.091 & 0.422 & 756494 & 9252352 & $\mathrm{Di}, \mathrm{CBA}, \mathrm{HT}, \mathrm{PAI}$ & $\begin{array}{l}\text { DWleaf,DWbranch, } \\
\text { Vol, PAI }\end{array}$ \\
\hline Veados (A16)-Degraded open Caatinga & 1.040 & 0.066 & 735750 & 9272196 & $\mathrm{Di}, \mathrm{CBA}, \mathrm{HT}, \mathrm{PAI}$ & $\begin{array}{l}\text { DWleaf,DWbranch, } \\
\text { Vol, PAI }\end{array}$ \\
\hline
\end{tabular}

${ }^{1 /} \mathrm{H}^{\prime}=$ Shannon-Waver diversity index; ${ }^{2 / D T ~} \mathrm{~m}^{-2}=$ Total Density $\left(\right.$ Trees per $\left.\mathrm{m}^{2}\right) ;{ }^{3} \mathrm{Di}=$ Distance from tree $\mathrm{i}$ to sampled point $(\mathrm{m}) ; \mathrm{CBA}=\mathrm{Base}$ circumference $(\mathrm{cm}) ; \mathrm{HT}=$ Total Height $(\mathrm{m})$; DC2 = product of higher and shorter crown diameter $(>\mathrm{DC} *<\mathrm{DC})\left(\mathrm{m}^{2}\right)$; PUF = Leaf Humid Weight $\left(\mathrm{g} \mathrm{tree}^{-1}\right) ; \mathrm{PUG}=$ Branch and Trunk Humid Weight $\left(\mathrm{g}_{\text {tree }}^{-1}\right) ; \mathrm{Vol}=$ volume $\left(\mathrm{m}^{3}\right.$ tree $\left.{ }^{-1}\right)$, measured by xilometer; ${ }^{4}$ DWbranch $=$ Branch Dry Weight $\left(\mathrm{kg} \mathrm{tree}^{-1}\right)$, using humid base humidity Table (UBU\%) of main species (Ibama, 1992a); DWleaf = Leaf Dry Weight $\left(\mathrm{kg}^{2}\right.$ tree $\left.{ }^{-1}\right)$, after drying in oven at $60^{\circ} \mathrm{C}$ temperature, for $48 \mathrm{~h}$; and PAI = Plant Area Index, indirectly measured in the field, using LAl2000 (Li-Cor, 1992) apparatus. 
The correlations between variables were analyzed as a first check of their effectiveness and of the quality of the equations. Trees occurring in the upper right quadrant, at each point, were standardized as trees for cutting. These trees were weighted in a field scale (0-5 $\mathrm{kg}$ and $2.5-15 \mathrm{~kg}$ ), and their volumes obtained with a xilometer (dimensions: $\mathrm{D}=1 \mathrm{~m}, \mathrm{H}=0.7 \mathrm{~m}, 1 \mathrm{~mm}$ graduated ruler, Accuracy $=1 \mathrm{dm}^{3}$ ). Leaf dry weight (DWleaf) was measured using a precision scale.

DWbranch, DWleaf and Vol parameters (dependent variables) were estimated on a per tree basis from dendometrical variables DWbranch, SCBA, HT and DC2 (independent variables). For DWleaf, the variable DATA (Dummy) was also considered for intercept, since data were collected on different dates during the rainy season, once in the stage in which plants had $100 \%$ leaves (March) and the second time when the dry season was coming to an end (June), with leaves already starting to fall, giving mean data for May.

Linear and logarithmic models were tested by the Stepwise procedure and non linear for the selection of the equations comparing them to two surveys carried out by Silva (1998) and Ibama (1992a). Criteria used to choose the best linear model were the determination coefficient $\left(R^{2}\right)$, variation coefficient of $(C V)$, and residues analysis. Considering the heterogeneity of data because of twisting and forking of individuals, and the shrub inclusion level (DBA $\geq 1 \mathrm{~cm}$ ), high variation coefficients were foreseen, and this was decisive for the selection of the best distribution of residues.

One alternative to the use of logarithmic models to reduce the heterogeneity of variances is the transformation suggested by Box \& Cox (1964), referred to and modified by Silva et al. (1993a). This model was used to estimate DWbranch as a function of SCBA and $H T$, resulting in the following function: DWbranch $=\left[b_{0}\left(b_{1}+b_{2}{ }^{*} S C B A+b_{3}{ }^{*} H T+e\right)+1\right]^{1 / b 0}$, and $b_{0}, b_{1}$, $b_{2}$ and $b_{3}$ are coefficients to be estimated, and $e=$ error.

Another model modified from the non linear Schumacher and Hall model, resulted from an academic exercise, with added effects of intercept and residue, as a variation of the original model. The same variables, DWbranch, SCBA and HT were also tested by this model, resulting in the function: DWbranch $=b_{0}+b_{1}{ }^{*} S C B A^{b 2 *} H T^{b 3}+e$, and $b_{0}, b_{1}, b_{2}$ e $b_{3}$ are coefficients to estimate, and $\mathrm{e}=$ error.

The best equations generated by previous surveys carried out at the caatinga by the PNUD/FAO/ Ibama project (Ibama, 1992a) and by Silva (1998) were also applied to data for validation, referring to areas 1,2 and 3 . The main differences between these surveys and the survey developed in this study are presented in Table 2.

Phytomass Estimates by Area as a Function of Dendrometrical Data (DWbranch, DWleaf and Vol) were produced from the equations selected from the methods and surveys described in Table 2, for all areas, supplying basic data for the second stage (Figure 2).

\section{Stages 2 and 3}

An LAl-2000 was used to Measure the PAI per Area which calculates the foliar area based on the diffuse energy ratio, B (Reading below the canopy)/A (Reading above the canopy) = T (transmitance), which is proportional to the distance from this energy to the detector, and the amount of leaves per crown volume, and leaf orientation. Readings were made with a $45^{\circ}$ view cap at sunrise and sunset and under cloudy skies, according to the following sequence: one reading $A$, and 10 readings $B$, and each reading $B$, measured over transect points, $10 \mathrm{~m}$ apart.

For Phytomass Estimates as a function of PAl/ NDVI (Phytomass Mapping), a NDVI image was generated with LANDSAT 7 TM bands 3 and 4, passage May/00 (rainy season). NDVI is calculated by: NDVI=(TM4-TM3)/ (TM4+TM3), in which TM4 and TM3 are radiance values for band 4 (close infrared) and band 3 (red). The PAI assumes the function of estimator of the phytomass (independent variable) which estimated by the NDVI (dependent variable) enables specializing the phytomass as a function of the NDVI, according to the functions: (PAl) $f(N D V I)$; and (DWtotal, DWleaf, Vol) $f(P A l)$.

\section{RESULTS AND DISCUSSION}

\section{Models to Estimate Phytomass by Tree, by Species}

The percentage trend between the estimated DWbranch value and DWtotal, and value measured in the field (real) of the models tested for areas 1, 2

Table 2 - Comparison between the phytomass estimate survey in the Caatinga area carried out in this study and the two previous ones.

\begin{tabular}{lcccccc}
\hline Source & $\begin{array}{c}\text { 1/DBA } \\
\text { minimum }\end{array}$ & $\begin{array}{c}\text { One Record } \\
\text { (individual) }\end{array}$ & $\begin{array}{c}\text { Stratification } \\
\text { (equation Local) }\end{array}$ & Model & Purpose & SITE \\
This study & $\geq 1 \mathrm{~cm}$ & tree & No & $\begin{array}{c}\text { Stepwise Method; Silva et } \\
\text { al. (1993a); Modified } \\
\text { Schumacher \& Hall Method sociological Inventory }\end{array}$ & $\begin{array}{c}\text { Phytomass Mapping } \\
\text { and Phyto- }\end{array}$ & $\begin{array}{c}\text { Jardim do } \\
\text { Parelhas-RN }\end{array}$ \\
$\begin{array}{l}\text { Silva } \\
(1998)\end{array}$ & $\geq 3 \mathrm{~cm}$ & forking & No & Potential & $\begin{array}{c}\text { Aerial Phytomass } \\
\text { Modeling }\end{array}$ & $\begin{array}{c}\text { Santa Luz-BA; } \\
\text { Petrolina-PE }\end{array}$ \\
$\begin{array}{l}\text { lbama } \\
(1992 a)\end{array}$ & $\geq 2 \mathrm{~cm}$ & forking & Yes & Linear & Forest Management & Núcleo \\
Plan (RN) & doSeridó-RN/PB
\end{tabular}

${ }^{1 / D B A}=$ base diameter 
and 3 is presented in Figure 3 . The inadequacy of equations generated by Silva (1998) is evidenced from the potential model which, in its theoretical form, is inadequate, since its relationship indicates that a reduction in diameter growth do not reduct the acceleration of the increment in phytomass, which occurs for height, and not for the diameter, since growth in height reduces relatively to the diameter until older plants stabilize.

Equations generated by Ibama (1992a) also had strong trends for areas 1 and 2, even with stratification, probably due to the more restricted approach, as compared to our survey, but with better results than the other methods for area 3. This is due to the DWbranch equation for DWbranch for the Pereiro species, which, in area 3 was cut, presenting significant forking. Since Ibama (1992a) modeled forking and not the tree, the accuracy of derived equations was better than ours for this species.

Among equations adjusted with data of the test areas (Stepwise Method, Modified Schumacher \& Hall Model, and Silva et al. (1993a)), no sereve, great variation was found between the $R^{2}$ and $C V$ results (Table 3 ). Thus, it was assumed that it was not necessary to measure the product of the larger and smaller crown diameters (DC2) from area 8, because this would make data collection more complex, although this variable improves accuracy significantly.

Main equations generated by the Stepwise method, are described in Table 4. Among DWleaf equations, the DATE variable was not significant for Aspidosperma pyrifolium Mart. (Pereiro), more resistant to leaf fall, and Jatropa pohliana (Pinhão Brabo) which still had most leaves in the second collection. In relation to the DC2 variable, the Pinhão Brabo was the only species that was not included as an explanatory variable for DWleaf.

To estimate the phytomass (Dwleaf and DWbranch) and the volume for the 16 areas a combination of the best equations generated by the Stepwise Method, Schumacher \& Hall Modified Model and Box \& Cox Transformation, Modified by Silva et al. (1993a) were chosen. For other species, less frequent in this region, with standard not similar to the ones that were modeled, the Tavares et al. (1969) 0.6 morphologic coefficient (shape factor) was adopted.

\section{Phytomass Equations as a Function of PAI/NDVI}

Correlations for each area between structural variables of vegetation, phytomass, PAI and NDVI are presented in Table 5. DWleaf is the variable with the largest correlation with PAI and NDVI, because of the almost total contribution of leaves to both indeces. Its relationship with the other structural vegetation variables (0.94 for DWbranch and Vol, 0.79 for DT m ${ }^{-2}, 0.78$ for B $\mathrm{ha}^{-1}$, and 0.75 for HT), explains the correlation of the other variables with NDVI. In addition, the structural and phytomass variables are better correlated to PAI as compared to NDVI, which justifies the use of PAI as an intermediate variable when estimating the phytomass by orbital parameters.

The resulting equation for DWtotal (DWbranch + DWleaf), having as explanatory variable PAI, is:

DWtotal $=-980.47+11.851 .25^{\star} \mathrm{PAl}, \mathrm{R}^{2}=76.48$, with data distribution expressed in Figure 4.

One drawback of this equation is its sensitivity to PAl variations, which on the other hand, is estimated as a function of NDVI. This means that consistent results require good adjustments of the PAI and NDVI relationships.

The relationship between PAI as a function of NDVI, obtained for bands 3 and 4 of the Landsat 7 ETM+ Sensor, resulted in the equation:

$P A I=0.6401^{*} \exp \left(2.6929^{*} \mathrm{NDVI}\right)$, with $\mathrm{R}^{2}=78.02$, represented in Figure 5.

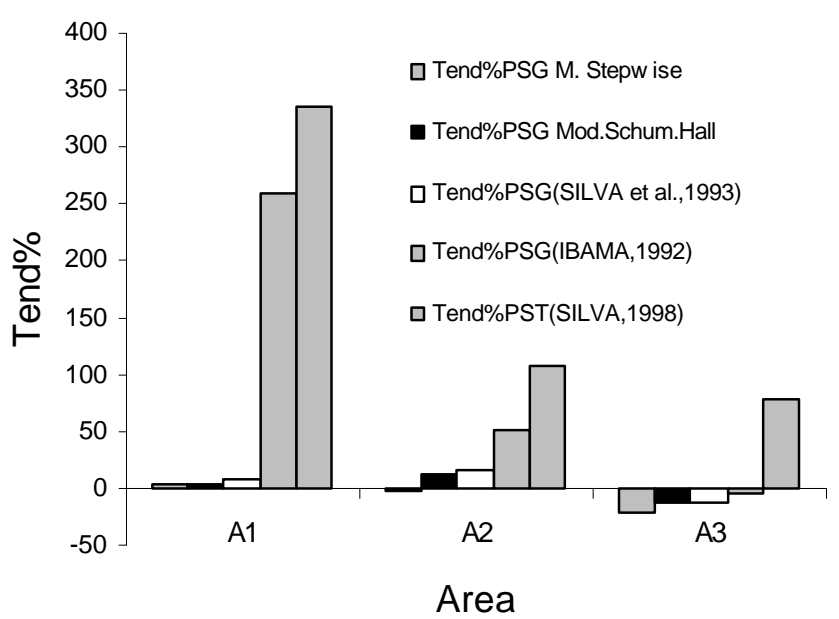

Figure 3 - Comparison between percentage trend (\%) of the Estimates of the equations adjusted by the Stepwise method, by the Modified Schumacher and Hall Model, by the Box \& Co transformation (1964), modified by Silva et al. (1993a), and equations from Ibama (1992a) and Silva (1998).

Table 3 - Determination coefficients $\left(\mathrm{R}^{2}\right)$ and Variation Coefficients (CV) of equations by species obtained by the Stepwise Method, Schumacher \& Hall Modified Model and Box \& Cox Transformation, modified by Silva et al. (1993a).

\begin{tabular}{lllllll}
\hline Species & \multicolumn{2}{c}{$\begin{array}{c}\text { Stepwise M. } \\
\text { Common name }\end{array}$} & $\mathrm{R}^{2}(\%)$ & $\mathrm{CV}$ & $\begin{array}{c}\text { Mod. Schum. } \\
\text { Hall M. }\end{array}$ & \multicolumn{2}{c}{$\begin{array}{c}\text { Silva et al. } \\
(1993 \mathrm{a})\end{array}$} \\
\hline Catingueira & 94.94 & 65.61 & 82.41 & 62.59 & 81.29 & 62.48 \\
Jurema & 85.14 & 84.78 & 82.81 & 60.70 & 70.84 & 73.93 \\
Marmeleiro & 40.67 & 70.21 & 36.77 & 71.40 & 36.10 & 71.85 \\
Mofumbo & 88.55 & 20.83 & 82.62 & 30.37 & 84.13 & 28.99 \\
Pereiro & 51.78 & 78.06 & 34.18 & 77.90 & 28.55 & 80.40 \\
Pinhão Brabo & 98.83 & 10.93 & 88.94 & 38.58 & 90.31 & 36.35 \\
\hline
\end{tabular}


Breakdown of DWtotal in DWbranch and DWleaf $\quad \mathrm{Vol}=0.001117^{*}$ DWbranch $+0.3537\left(R^{2}=99.97\right)$ can also be obtained as according to the equations:

The errors that contributed most to the low DWleaf $=147.53^{\star} \exp \left(0.9518^{\star} \mathrm{PAI}\right)\left(\mathrm{R}^{2}=81.62\right)$, expressed in Figure 6.

DWbranch $=$ DWtotal - DWleaf determination coefficients occurred for the intermediate density areas, which correspond to areas with clearings, with a cluster-type distribution of individuals (A9, A10 and

Table 4 - Equations generated by the Stepwise Method for DWbranch, DWleaf and Vol, per tree of the most abundant species in Seridó (Ibama, 1992a) (Independent variables: SCBA-Sum of circumferences at the base; HT-Total height; DC2-Product of the largest and shorter crown diameter; DATE: $1=13-17 / 03 / 2000,2=5-15 / 06 / 2000)$.

\begin{tabular}{|c|c|c|c|c|}
\hline Popular Name & Equations & $\mathrm{n}$ & $\mathrm{R}^{2}$ & CV \\
\hline \multirow{2}{*}{ Catingueira } & DWbranch $=\exp \left(-2.00098+0.68578^{*} \ln D C 22.01737^{*} \operatorname{InHT}+0.00002 * \mathrm{SCBA} 2^{*} \mathrm{HT}\right)$ & 22 & 94.94 & 65.61 \\
\hline & DWleaf $=\exp \left(0.39229+1.07911^{*} \operatorname{InDC} 2-1.16239 * \mathrm{DATE}-0.43648^{*} \mathrm{HT}\right)$ & & 67.70 & 119.84 \\
\hline \multirow{2}{*}{$\begin{array}{l}\text { Caesalpinea } \\
\text { Pyramidalis Tul. }\end{array}$} & Vol $=0.000143+0.001033^{*}$ Dwbranch & & 99.65 & 7.63 \\
\hline & ${ }^{2 / D W b r a n c h}=-11.4435+4.6677^{*} \mathrm{HT}+0.7629^{*} \mathrm{DC} 2$ & & 92.52 & - \\
\hline${ }^{1 / F a v e l e i r a ~}$ & DWbranch $=1.817077+0.001131 *$ SCBA2HT & 3 & 99.00 & - \\
\hline Cnidoscolus & DWleaf $=-0.004946+0.028849 *$ Dwbranch & & 99.95 & - \\
\hline $\begin{array}{l}\text { Phyllacanthus } \\
\text { (M.Arg.) Pax. }\end{array}$ & Vol $=0.000018+0.001216 *$ Dwbranch & & 99.99 & - \\
\hline Jurema Preta & DWbranch $=\exp \left(-4.41185+0.52757^{*} \operatorname{InSCBA} 2 \mathrm{HT}+1.59278^{*} \operatorname{InHT}\right)$ & 35 & 84.43 & 84.78 \\
\hline \multirow[t]{2}{*}{$\begin{array}{l}\text { Mimosa tenuiflora } \\
\text { (Willd.) Poir. }\end{array}$} & $\begin{array}{l}\text { DWleaf }=1.513569+0.095785^{\star} \text { DC2 }+0.000014^{\star} \text { SCBA2HT-0.714134*DATA-0.13- } \\
653^{*} \mathrm{HT}\end{array}$ & & 82.54 & 61.13 \\
\hline & Vol $=0.000518+0.001069 *$ Dwbranch & & 96.30 & 27.39 \\
\hline Marmeleiro & DWbranch $=0.322366+0.000291 *$ SCBA2HT +0.159221 *DC2 & 95 & 37.51 & 70.21 \\
\hline Croton & DWleaf $=\exp \left(-0.46888-1.13672^{*} \mathrm{DATA}+0.35081^{*} \ln P S G+0.37536^{*} \operatorname{InDC} 2\right)$ & & 51.64 & 89.74 \\
\hline $\begin{array}{l}\text { Sonderianus } \\
\text { Muell.Arg. }\end{array}$ & Vol $=0.000261+0.001135^{\star}$ Dwbranch & & 61.49 & 56.93 \\
\hline Mofumbo & DWbranch $=-1.21869+1.50961^{*} \operatorname{InDC} 2+2.79937^{*} \operatorname{InHT}$ & 8 & 88.55 & 20.83 \\
\hline \multirow[t]{2}{*}{$\begin{array}{l}\text { Combretum } \\
\text { leprosum Mart. et } \\
\text { Eichl }\end{array}$} & $\begin{array}{l}\text { DWleaf }=-3.52906+0.08471^{*} \mathrm{DC} 2+1.39177^{*} \mathrm{DATA}+0.24535^{*} \text { Dwbranch }- \\
0.78842^{*} \ln P S G+0.36613^{*} \ln \mathrm{DC} 2+0.58452^{*} \operatorname{InHT}\end{array}$ & & 99.81 & 3.98 \\
\hline & Vol $=\exp \left(-7.01306+1.2414^{*} \operatorname{InPSG}\right)$ & & 99.22 & 23.31 \\
\hline Pereiro & $\begin{array}{l}\text { DWbranch }=\exp \left(-1.42515+0.61114^{*} \operatorname{InDC} 2+0.75086^{*}\right. \\
\text { InHT+0.17284*InSCBA2HT) }\end{array}$ & 50 & 51.79 & 78.05 \\
\hline Aspidosperma & DWleaf $=-0.016943+0.167037^{*}$ DWbranch $-0.00003^{*} \mathrm{SCBA}{ }^{*} \mathrm{HT}+0.058898^{*} \mathrm{DC} 2$ & & 67.90 & 70.81 \\
\hline Pyrifolium Mart. & Vol $=0.000145+0.001163^{*}$ Dwbranch & & 98.27 & 75.39 \\
\hline $\begin{array}{l}\text { Pinhão } \\
\text { Brabo }\end{array}$ & $\begin{array}{l}\text { DWbranch }=\exp \left(-2.5168+0.67569^{*} \ln \mathrm{DC} 2+0.08316 * \mathrm{SCBA}+0.95312^{*} \mathrm{HT}-\right. \\
\left.1.73677^{*} \ln \mathrm{HT}\right)\end{array}$ & 12 & 98.83 & 10.93 \\
\hline Jatropa & DWleaf $=\exp \left(0.07366-2.16276^{\star} \mathrm{DATA}+0.00087^{\star} \mathrm{SCBA} 2 \mathrm{HT}\right)$ & & 88.01 & 54.38 \\
\hline $\begin{array}{l}\text { Pohliana (Pohl)- } \\
\text { Baill. Var Velutina }\end{array}$ & Vol $=-0.000313+0.001694^{\star}$ DWbranch $-0.00074 * \ln P S G$ & & 98.93 & 10.55 \\
\hline
\end{tabular}

${ }^{1 / A d j u s t e d ~ e q u a t i o n s ~ t o ~ r e p l a c e ~ t h e ~ g e n e r a l ~ e q u a t i o n, ~ w i t h o u t ~ s t a t i s t i c a l ~ e v i d e n c e . ~}$

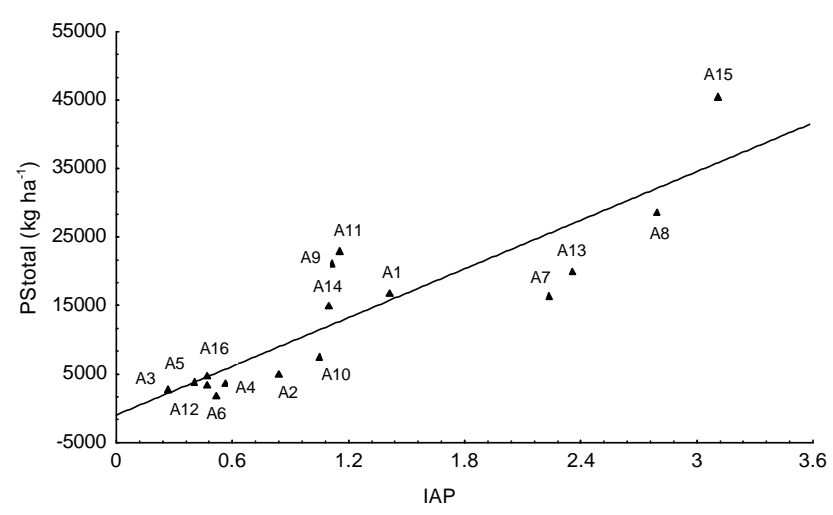

Figure 4 - Total Dry Weight (DWtotal) as a function of the Plant Area Index (PAl) for sampled areas.

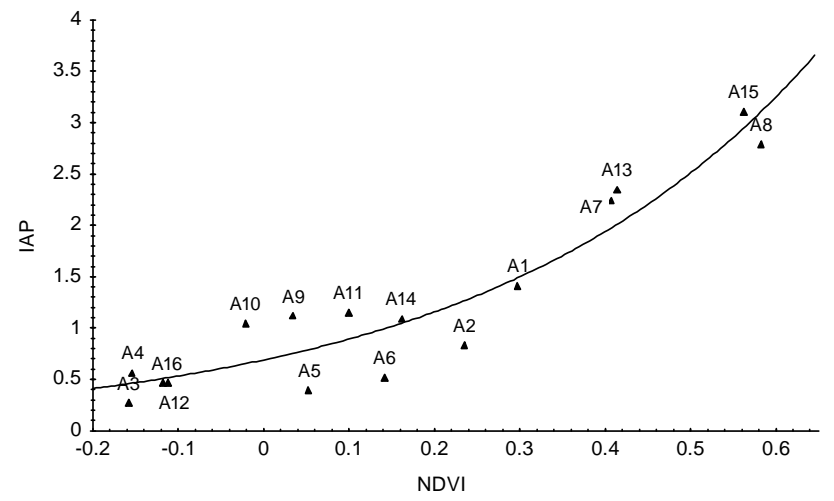

Figure 5 - Plant Area Index (PAI) as a function of NDVI for sampled areas. 
A11), and areas with abundant herbaceous plants, mainly "malva" and "capim panasco" (A2, A5 e A6). Areas with clearings may underestimate the NDVI, by means of soil saturation, while the presence of herbaceous type coverage contributes to NDVI, leading to overestimates for the tree-bush portion.

The evaluation of mapping errors by comparing phytomass estimated as a function of PAI/NDVI to the phytomass estimated based on dendrometrical variables is shown in Table 6 . The percentage deviation ranged from 0 (A12) to $84 \%$ (A5) for PAl, and from $5 \%$ (A1 and A12) to $448 \%$ (A6) for DWtotal. For DWleaf, errors ranged from $8 \%(A 13$ and $A 16)$ to $250 \%(A 6)$. Vol ranged from $0 \%(A 1)$ to $432 \%(A 6)$. The significant deviation in area 6 was confirmed for all variables, since this area had a low tree density, but significant herbaceous coverage represented by malva and capim panasco. Low accuracy is then assessed in phytomass mapping. As the final information is generated in a thematic form, in which data are grouped in classes, accuracy is improved by generalization.
The final product of the Categorized DWtotal map is presented in Figure 7 with the following distribution: $27 \%$ of the study area corresponds to the following classes: "pasture", "agriculture", "dam", "riverine vegetation" and "urban zone"; while $73 \%$ is covered by caatinga.

Relatively to caatinga phytomass, $13 \%$ of the area was found to have 0.1 to $5 \mathrm{Mg} \mathrm{ha}^{-1}$ of Total Dry Weight, in the Northwest portion of the area and $30 \%$ had 5 to 10 $\mathrm{Mg} \mathrm{ha}^{-1}$. These two phytomass classes, distributed in $43 \%$ of the area, occurred mainly over non calcic brown soils that in the past were frequently planted with cotton.

Phytomasses between 10 and $20 \mathrm{Mg} \mathrm{ha}^{-1}$ were found in $21 \%$ of the area, and values above $20 \mathrm{Mg} \mathrm{ha}^{-1}$, associated mainly to Dense Caatinga, covered $9 \%$ of the area, mainly the Queimadas hills on the Southeast. Areas A7, A8 A15 are in this region, with a large diversity of species and the tallest trees, mostly over litholic soils. The fact that most preserved vegetation was found mainly in the hills is evident and this results from restriction to anthropic activity except for mining activities that are very common in the region.

Table 5 - Pearson Correlation between the Phytomass, Vegetation Structure, PAI and NDVI variables for all areas ( $\mathrm{n}=16$ ) (significant values $P<0.05$ ).

\begin{tabular}{|c|c|c|c|c|c|c|c|c|}
\hline & DT $m^{-2}$ & DWbranch & DWleaf & ${ }^{1 / D W}$ total & Vol & $\mathrm{HT}$ & ${ }^{2 / B}$ & NDVI \\
\hline & & - & $--\mathrm{kg} \mathrm{ha}^{-1}$ & 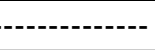 & $\mathrm{m}^{3} \mathrm{ha}^{-1}$ & $\mathrm{~m}$ & $\mathrm{~m}^{2} \mathrm{ha}^{-1}$ & \\
\hline PAI & 0.89 & 0.88 & 0.93 & 0.88 & 0.88 & 0.67 & 0.77 & 0.91 \\
\hline NDVI & 0.76 & 0.76 & 0.84 & 0.76 & 0.76 & 0.61 & 0.66 & 1.00 \\
\hline
\end{tabular}

${ }^{1 /}$ DWtotal = DWbranch + DWleaf; ${ }^{2 / B}=$ basal area

Table 6 - Percentage deviations (E\%) for DWtot, DWleaf, Vol and PAI, estimated with the Phytomass equations from PAI/ NDVI.

\begin{tabular}{|c|c|c|c|c|c|c|c|c|c|c|c|c|}
\hline & DWtot & ${ }^{2}$ DWtot & E\% PStot & ${ }^{1 / D W l e a f}$ & ${ }^{2}$ DWleaf & E\% DWleaf & ${ }^{1 /} \mathrm{Vol}$ & ${ }^{2} \mathrm{Vol}$ & $\mathrm{E} \% \mathrm{Vol}$ & PAI & ${ }^{2} \mathrm{PAl}$ & E\% PAI \\
\hline \multicolumn{7}{|c|}{ 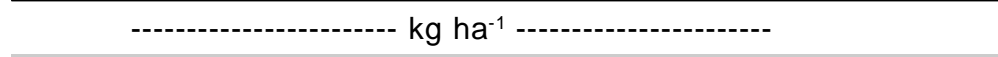 } & \multicolumn{6}{|c|}{$---\mathrm{m}^{3} \mathrm{ha}^{-1}----$} \\
\hline A1 & 16786 & 15931 & -5 & 1266 & 574 & -55 & 18 & 18 & 0 & 1.42 & 1.43 & 1 \\
\hline A2 & 4987 & 13273 & 166 & 368 & 463 & 26 & 6 & 15 & 165 & 0.84 & 1.20 & 44 \\
\hline A3 & 2735 & 3972 & 45 & 173 & 220 & 27 & 3 & 5 & 44 & 0.27 & 0.42 & 57 \\
\hline A4 & 3715 & 4038 & 9 & 183 & 221 & 20 & 4 & 5 & 7 & 0.57 & 0.42 & -26 \\
\hline A5 & 3800 & 7761 & 104 & 148 & 298 & 101 & 5 & 9 & 90 & 0.40 & 0.74 & 84 \\
\hline A6 & 1848 & 10119 & 448 & 103 & 360 & 250 & 2 & 11 & 432 & 0.52 & 0.94 & 81 \\
\hline A7 & 16462 & 21728 & 32 & 1071 & 914 & -15 & 18 & 24 & 31 & 2.24 & 1.92 & -14 \\
\hline A8 & 28596 & 35342 & 24 & 1653 & 2728 & 65 & 31 & 37 & 20 & 2.79 & 3.06 & 10 \\
\hline A9 & 21187 & 7337 & -65 & 638 & 288 & -55 & 23 & 8 & -65 & 1.12 & 0.70 & -37 \\
\hline A10 & 7426 & 6191 & -17 & 400 & 262 & -34 & 8 & 7 & -14 & 1.05 & 0.61 & -42 \\
\hline A11 & 22995 & 8954 & -61 & 784 & 328 & -58 & 25 & 10 & -59 & 1.15 & 0.84 & -27 \\
\hline A12 & 4769 & 4546 & -5 & 308 & 230 & -25 & 5 & 5 & -5 & 0.47 & 0.47 & 0 \\
\hline A13 & 20074 & 22168 & 10 & 1031 & 947 & -8 & 22 & 24 & 8 & 2.36 & 1.95 & -17 \\
\hline A14 & 15118 & 10740 & -29 & 569 & 378 & -34 & 16 & 12 & -28 & 1.10 & 0.99 & -10 \\
\hline A15 & 45562 & 33568 & -26 & 2590 & 2365 & -9 & 48 & 35 & -27 & 3.11 & 2.92 & -6 \\
\hline A16 & 3384 & 4629 & 37 & 214 & 231 & 8 & 4 & 5 & 35 & 0.47 & 0.47 & 2 \\
\hline
\end{tabular}

${ }^{1 / E s t i m a t e s ~ p e r ~ d e n d r o m e t r i c a l ~ p a r a m e t e r s ; ~}{ }^{2 /}$ Estimates per orbital parameters. 


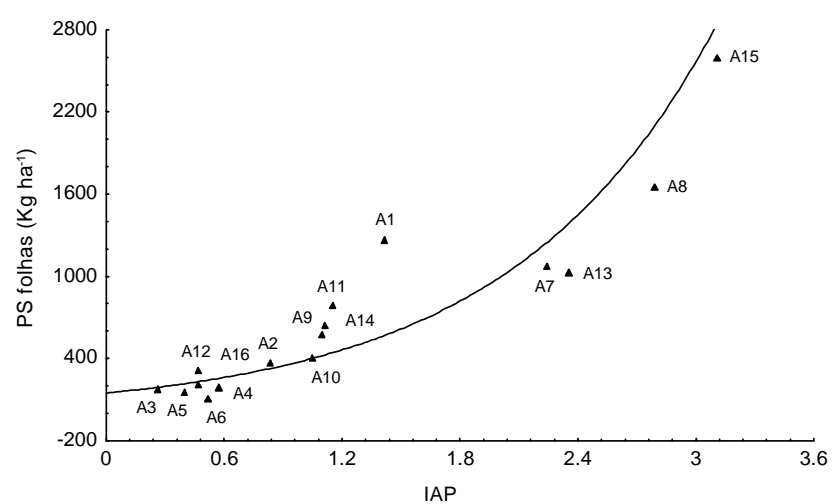

Figure 6 - Leaf Dry Weight (DWleaf) as a function of Plant Area Index (PAI) for sampled areas.

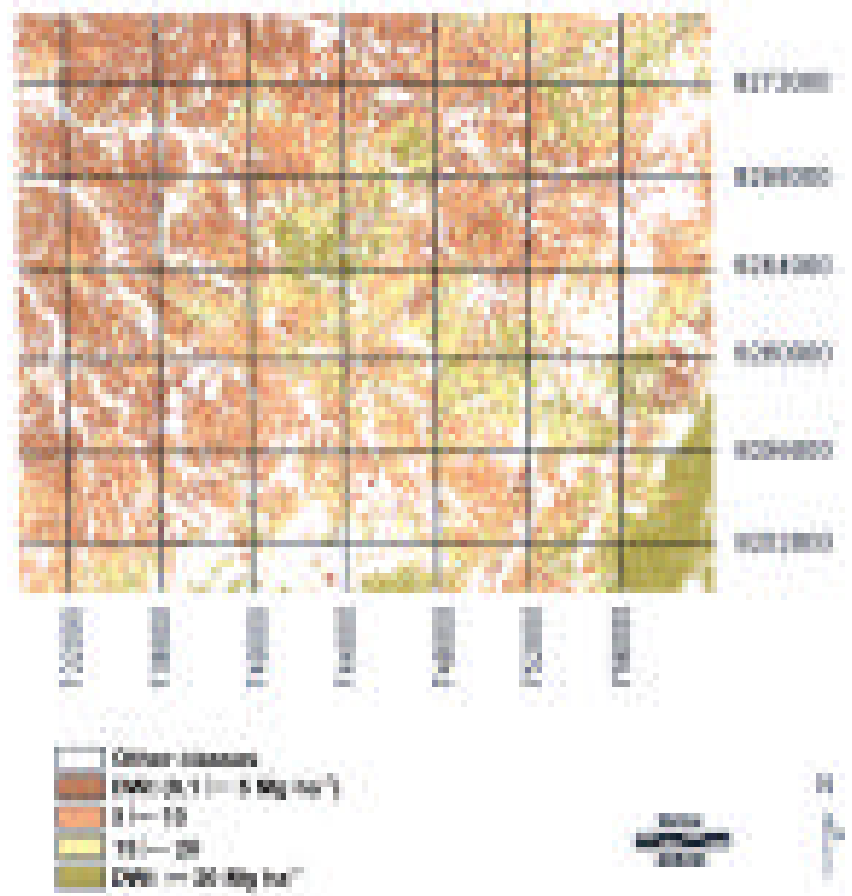

Figure 7 - Total Dry Weight (DWtotal=DWbranch+DWleaf) in $\mathrm{Mg}$ ha ${ }^{-1}$ for the study area at Seridó Nucleus.

\section{Phytomass as input for Environmental Studies}

\section{Erosion}

Phytomass mapping can be a source of data for the zoning of areas susceptible to desertification, when associated to other parameters such as topography, soil, climate, land use, etc. In the Universal soil loss equation (USLE), Troeh et al. (1991), for example, phytomass enables increased accuracy of the $C$ parameter (Land Use/Coverage factor), replacing the rigid structure per weight of vegetation class.

\section{$\mathrm{CO}_{2}$ Absorption by Caatinga}

Taking into account the loss of leaves, since semi-arid climate of the caatinga is a canopy typology in which leaves fall completely in the dry season, the average amount of leaves shed (DWleaf) totals $386 \mathrm{~kg}$ $\mathrm{ha}^{-1}$ year ${ }^{-1}$ for this area, ranging from $701 \mathrm{~kg} \mathrm{ha}^{-1}$ year $^{-1}$ for the Dense Caatinga to $276 \mathrm{~kg} \mathrm{ha}^{-1}$ year ${ }^{-1}$ for the open caatinga, on average.

Using a $48 \%$ dry carbon factor in the dry matter (Phillips et al., 1998), the gross rate of the carbon sink for this region, considering only the annual fall of leaves, totals $185 \mathrm{~kg} \mathrm{C} \mathrm{ha}^{-1}$ year $^{-1}$ or $678 \mathrm{~kg} \mathrm{CO}_{2}$ ha $^{-1}$ year ${ }^{-1}$, which corresponds to $26 \%$ of the carbon entrapped by the tropical forest, which is $710 \pm 340 \mathrm{~kg} \mathrm{C}^{-1}$ year $^{-1}$ (Phillips et al., 1998), a considerable proportion for caatinga fragments in a desertification nucleus.

\section{Forest Inventory}

The RN Seridó Region was the object of a comprehensive study carried out in the PNUD/FAO/ IBAMA/BRA/87/007 project, part of the Brazilian Northeast integrated forest development program (Ibama, 1992a, b e c), which goes from diagnosis to the definition of strategies and simulation of scenarios. A phytomass mapping in a SIG environment could contribute to this study by providing management and processing support, such as the indication of appropriate areas for forest management, the amount of timber available, among other information that can be readily made available.

Focusing on this pilot area, $33 \%$ of the area has a volume of timber above $10 \mathrm{~m}^{3} \mathrm{ha}^{-1}$. If we consider a volume above $15 \mathrm{~m}^{3} \mathrm{ha}^{-1}$ this percentage drops to $17 \%$ of the area that would have required conditions for sustainable development, and it is also necessary to deduct non usable timber, environmental interest areas and areas in a topographic situation which is not recommended for forestry activities. .

When relating the mean increment rate taken from Ibama (1992a), totaling $530,45 \mathrm{~kg} \mathrm{ha}^{-1}$ year ${ }^{-1}$ in the Seridó region, or $0.5894 \mathrm{~m}^{3} \mathrm{ha}^{-1}$ year ${ }^{-1}$, using a mean conversion factor, $\mathrm{Vol} / \mathrm{DWbranch}$, we have the gross available volume of $7,409 \mathrm{~m}^{3}$ year $^{-1}$ in the area with stock above $15 \mathrm{~m}^{3} \mathrm{ha}^{-1}$, which is 12,571 ha. Thus, the remaining volume of this pilot area representing $9 \%$ of the whole Serido nucleus, contributed with $18 \%$ of the demand projected for 2001 (Ibama, 1992b).

\section{Canopy Coverage Monitoring}

Among main experiences of coverage monitoring and land use in the Brazilian territory, the best known is the "Prodes-Projeto de Estimativa do Desflorestamento da Amazônia Legal", (Legal Amazon Deforesting Estimate Project) aiming at the systematic monitoring of the region and assessment of the evolution of the extension and the annual gross deforesting rate. Phytomass mapping associated with a monitoring system focusing on forest exploitation and agriculture-cattle breeding expansion (Costa et al., 2000) adds important information, besides deforested areas and regenerating areas which correspond to suppressed or regenerated phytomass from the use of the land.

Thus, we deem that even if relationships between orbital and biophysical parameters of caatinga vegetation still lack accuracy, the use of remote sensing to estimate 
the tree-shrub phytomass makes for improved operation at low cost, and represents an alternative to regional applications.

\section{ACKNOWLEDGMENTS}

To CNPq for the invested resources and staff. Dra. Maria do Carmo from IPA, for laboratory support, interns Ana Luiza da Silva, Eudmar da S. Alves and Ricardo A. Irmão for the help in data collection and typing, and, Ademar Barros da Silva and Paulo Cardoso de Lima of Embrapa Solos Nordeste; Rinaldo M. Santos and José Antônio Aleixo da Silva, of for the Department of Forest Engineering at UFRPE for the collaboration in the prereview of this work.

\section{REFERENCES}

AMARAL, S.; SOARES, J.V.; ALVES, D.S.; MELLO, E.M.K.; ALMEIDA, S.A.S.; SILVA, O.F.; SILVEIRA, A.M. Relações entre índice de área foliar (LAI), área basal e índice de vegetação (NDVI) em relação a diferentes estágios de crescimento secundário na Floresta Amazônica em Rondônia. (Compact disc). In: SIMPÓSIO BRASILEIRO DE SENSORIAMENTO REMOTO, 8. Salvador, 1996. Anais. Salvador: INPE; SELPER, 1996.

BOHRER, C.B.A.; CAMPOS, A.N.S. Estimativa da fitomassa florestal na Amazônia legal a partir de dados provenientes de inventário florestal In: CONGRESSO FLORESTAL PANAMERICANO, 1.; CONGRESSO FLORESTAL BRASILEIRO, 7., Curitiba, 1993. Anais. São Paulo: SBS; SBEF, 1993. v.2, p.511-512.

BROWER, J.E.; ZAR, J.H.; VON ENDE, C.N. Field and laboratory methods for general ecology. New York: McGraw-Hill, 1998. 273p.

BROWN, S.; GILLESPIE, A.J.R.; LUGO, A.E. Biomass estimation methods for tropical forests with applications to forest inventory data. Forest Science, v.35, p.881-902, 1989.

COSTA, T.C.C.; VARGAS FILHO, R.; COELHO, L.M.; MIRANDA, L.H.F.; LOBATO, J.N. Sistema de monitoramento da cobertura vegetal de Minas Gerais - Integração com a fiscalização florestal do Instituto Estadual de Florestas - IEF/MG. (Compact disc). In: GIS, 6., Salvador, 2000. Anais. Salvador: Fator GIS, 2000.

FOODY, G.M.; PALUBINSKAS, G.; LUCAS, R.M.; CURRAN, P.J.; HONZAK, $M$. Identifying terrestrial carbon sinks: classification of succession stages in regenerating tropical forest from Landsat TM data. Remote Sensing of Environment, v.55, p.205-216, 1996.

GUIMARÃES, D.P.; LEITE, H.G. Um novo modelo para descrever o perfil do tronco. Revista Árvore, v.16, p.170-180, 1992.

IBAMA. Plano de manejo florestal para a região do Seridó do Rio Grande do Norte. Natal: IBAMA, 1992a. v.1 (Projeto PNUD/FAO/IBAMA)

IBAMA. Plano de manejo florestal para a região do Seridó do Rio Grande do Norte. Natal: IBAMA, 1992b. v.2 (Projeto PNUD/FAO/IBAMA)

IBAMA. Plano de manejo florestal para a região do Seridó do Rio Grande do Norte. Natal: IBAMA, 1992c. v.3 (Projeto PNUD/FAO/IBAMA)

JAKUBAUSKAS, M.E.; PRICE, K.P. Empirical relationships between structural and spectral factors of Yellowstone lodgepole pine forest. Photogrammetric Engineering and Remote Sensing, v.63, p.1375-1381, 1997.

KAZMIERCZAK, M.L. Estimativa de variáveis dendrométricas em florestas homogêneas a partir de dados LANDSAT TM. São José dos Campos, 1992. 186p. Dissertação (Mestrado) - Instituto Nacional de Pesquisas Espaciais.

LEITE, H.G.; REGAZZI, A.J. Métodos estatísticos para avaliar a igualdade de equações volumétricas. Revista Árvore, v.16, p.59-71, 1992.
LI-COR. LAI-2000 Plant Canopy Analyzer: operating manual. Lincoln: LICOR, 1992.

LINHARES, C.A.; PONZONI, F.J.; SHIMABUKURO, Y.E. Relação entre volume de madeira e índice de área foliar em um povoamento de Pinus spp.: Estudo de Caso. Revista Árvore, v.24, p.47-54, 2000.

PAULA NETO, F.; NUNES, J.R.S.; VITAL, B.R.; SOUZA, A.L. Equações de volume de casca de Eucalyptus de diferentes idades e condições de local, espécie e método de regeneração. Revista Árvore, v.16, p.157-169, 1992.

PAULA NETO, F.; REZENDE, A.V. Equações de fatores de empilhamento e Tables de volumes em metros estere para árvores individuais. Revista Árvore, v.16, p.72-87, 1992.

PEREIRA, M.D.B. Correlação de fitomassa verde de campo cerrado com dados espectrais obtidos pelo sistema MSS-Landsat e por radiometria de campo. São José dos Campos, 1985. Dissertação (Mestrado) - Instituto Nacional de Pesquisas Espaciais.

PHILLIPS, O.L.; MALHI,Y.; HIGUCHI, N.; LAURANCE, W.F.; NÚÑEZ, P.V. VÁSQUEZ, R.M.; LAURANCE, S.G.; FERREIRA, L.V.; STERN, M.; BROWN, S.; GRACE, J. Changes in the carbon balance of tropical forests: evidence from long-term plots. Science, v.282, p.439-442, 1998.

QI, J.; KERR, Y.H.; MORAN, M.S.; WELTZ, M.; HUETE, A.R.; SOROOSHIAN; S.; BRYANT, R. Leaf area index estimates using remotely sensed data and BRDF model in a semiarid region. Remote Sensing of Environment v.73, p.18-30, 2000.

SANTOS, J.R. Fitomassa aérea da vegetação de cerrado: estimativa e correlação com dados do sensor "Thematic Mapper" do satélite LANDSAT. Curitiba, 1988. 156p. Tese (Doutorado) - Universidade Federal do Paraná.

SANTOS, J.R.; LACRUZ, M.S.P.; KEIL, M.; KUX, H.J.H.; XAUD, M.R. Análise da imagem JERS-1 para estimativa da fitomassa aérea de florestas tropicais no sudoeste da Amazônia. (Compact disc). In: SIMPÓSIO BRASILEIRO DE SENSORIAMENTO REMOTO, 9., Santos, 1998. Anais Santos: INPE; SELPER, 1998.

SCOLFORO, J.R.; LIMA, J.T.; SILVA, S.T. Equações de fitomassa e volume para cerrado senso stricto. In: CONGRESSO FLORESTAL PANAMERICANO, 1.; CONGRESSO FLORESTAL BRASILEIRO, 7. Curitiba, 1993. Anais. São Paulo: SBS; SBEF, 1993. v.2, p.508-510.

SILVA, G.C. Relações alométricas de dez espécies vegetais e estimativas de fitomassas aéreas da Caatinga. Recife, 1998. Tese (Doutorado) Universidade Federal Rural de Pernambuco.

SILVA, J.A.A.; MELO, M.R.C.S.; BORDERS, B.E. A volume equation for mangrove trees in northeast Brazil. Forest Ecology and Management, v.58, p.129-136, 1993a.

SILVA, J.A.A.; MEUNIER, I.M.J.; BORDERS, B.E.; FARIAS, G.G.A.; ASSUNÇÃO, E. P. Equação volumétrica para Eucalyptus camaldulensis, na região de Barbalha, Ceará, usando o volume da primeira tora como variável independente. Revista Árvore, v.17, p.30-37, 1993b.

SOUZA, A.L.; JESUS, R.M. Equações de volume comercial e fator de forma para espécies da Mata Atlântica ocorrentes na reserva florestal da Companhia Vale do Rio Doce, Linhares, ES. Revista Árvore, v.15, p.257273, 1991.

TAVARES, S.; PAIVA, F.A.F.; TAVARES, E.J.S.; LIMA, J.L.S. Inventário florestal do Ceará. Estudo preliminar das matas remanescentes do Município de Quixadá. Boletim de Recursos Naturais, v.7, p.93-111, 1969.

TROEH, F.R.; HOBBS, J.A.; DONAHUE, R.L. Soil and conservation. New Jersey: Prentice-Hall, 1991. 530p.

WHITE, M.A.; ASNER, G.P.; NEMANI, R.R.; PRIVETTE, J.L.; RUNNING, S.W. Measuring fractional cover and leaf index in arid ecosystems: digital camera, radiation transmittance, and laser altimetry methods. Remote Sensing of Environment, v.74, p.45-57, 2000.

XAVIER, A.C.; SOARES, J.V.; ALMEIDA, A.C.; FREITAS, C.C. Estimativa de LAI de plantações de eucaliptos a partir de dados TM/LANDSAT. (Compact disc). In: SIMPÓSIO BRASILEIRO DE SENSORIAMENTO REMOTO, 9., Santos, 1998. Anais. Santos: INPE; SELPER, 1998.

Received February 16, 2001 